\title{
Essential Causes Of The Critical Site Coordination Problems In Building Projects: A Hong Kong Study
}

\author{
K.W. Andy NG \\ Division of Building Science and \\ Technology, City University of Hong Kong \\ bsandyng@cityu.edu.hk
}

\author{
Andrew D.F. Price \\ Department of Civil \& Building \\ Engineering, Loughborough \\ University, U. K. \\ a.d.f.price@lboro.ac.uk
}

DOI 10.5592/otmcj.2014.1.7

Research paper

\section{Keywords}

Subcontracting, Site Coordination Problem, Performance, Building projects
IN HONG KONG, MAIN CONTRACTORS OF BUILDING PROJECTS TEND TO SUBCONTRACT MOST OF THEIR WORK. HOWEVER, MANY OF THE SUBCONTRACTORS COMPLAIN THAT THEY ARE UNABLE TO PERFORM TO THEIR FULL CAPACITY DUE MAIN CONTRACTORS' POOR SITE COORDINATION OF TEMPORARY WORKS AND INTERFACING WORKS AND PLANT SUPPORTS ETC. Six critical site coordination problems caused by main contractors that had adversely influence to the performance of subcontractors were identified in previous study. Twelve essential causes to the problems were identified from literatures and previous studies. A questionnaire survey was conducted to establish a model that explain how the essential causes contributed to the occurrence of the critical site coordination problems which subsequently affected the performance of subcontractors. The survey results were validated by neural network analysis. Backward elimination method was adopted to identify the 'most essential' causes that enable main contractors to formulate measures to eliminate the critical site coordination problems. The survey findings show that 'design of the temporary work provided by main contractor cannot meet the requirements requested by the subcontractors' is the 'most essential' causes of four out of the six critical site coordination problems. 


\section{INTRODUCTION}

Subcontracting system is very important to the Hong Kong construction industry as labour-only subcontractors and fee subcontractors contributed more than 20 per cent and 40 per cent of the gross value of construction work performed in the last few years according to government statistics. Usually, main contractors would split the project into work packages by trade and sublet them to the first layer trade subcontractors. The first layer trade subcontractors further split their work packages into smaller packages and sublet them to the another layer of subcontractors. The subletting process may sometimes go down several more layers and can be characterised as multilayered subcontracting. This approach has been in operation for a long period of time in Hong Kong as a strategy to deal with long-term environmental uncertainties and to buffer the technical core of main contractors against short-term contingencies (Sozen, 1999). This system demands closely control on subcontractors' site work. With rapid development in terms of size and complexity of local building projects, there are increasing complaints from subcontractors that they are unable to efficiently and effectively perform their site works due to main contractors' poor site coordination. As the role of main contractors have gradually transformed from a constructor to a manager of subcontractors of projects, the performance of subcontractors was thus increasingly affecting the outcome of local building projects.

\section{Aim}

This paper aims to develop a model to explain how the essential causes contributed to the occurrence of the critical site coordination problems affecting the performance of subcontractors in Hong Kong building projects. Based on the model developed by Kinnear and Gray (2009), Figure 1 was formulated that classify the nature of the research

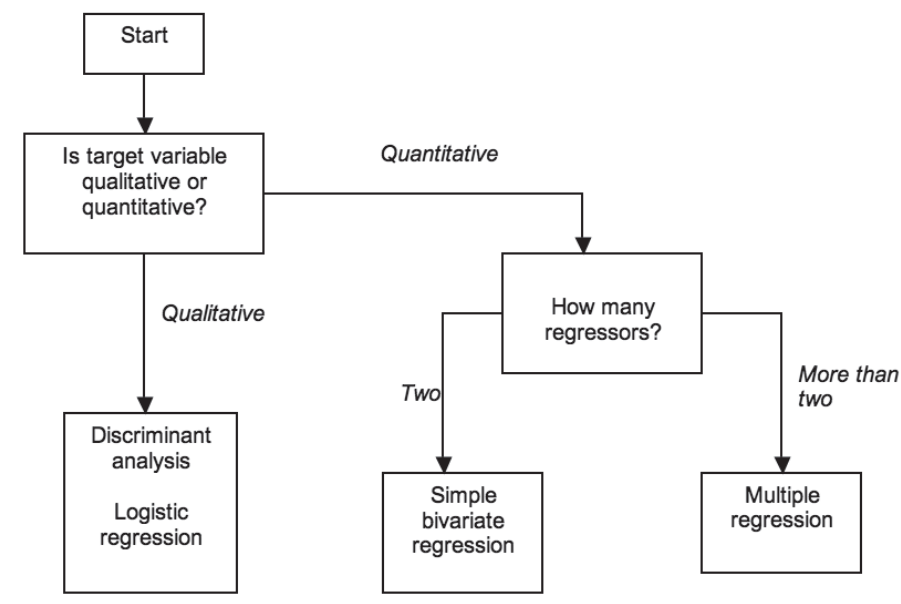

Figure 1. Statistical technique selection flow-chart

(adapted from Kinnear and Gray, 2009)

work into five types for the selection of the appropriate statistical technique for data analysis for this study. As the nature of this research relates to the prediction of outcomes, multiple regression analysis is considered as an appropriate approach for this study. The aim was achieved through the following objectives.

(a) Develop multiple regression equations to explain how the twelve essential causes contributed to the occurrence of the six critical coordination problems

(b) Identify the 'most essential' causes by backward elimination method that enables main contractors to develop measures to avoid the occurrence of the critical site coordination problems

This study only covered building projects as Hong Kong based civil engineering main contractors do not sublet as much of their works to subcontractors, mainly due to less labour being required.

\section{Literature Review}

There has been considerable research aimed at identifying the determinants for the performance of the contractor in building projects, however, most were focussed at the main contract level only. There are only a few publications that analyse the performance of subcontractors in the building projects. The literature review mainly covered similar studies at the main contract level in order to extract the relevant information which could be modified to suit the nature of this research. The common site coordination problems and the essential causes to these problems were identified by studying the publications for the factors affecting the productivity at the site work level. The study on success factors of Hong Kong projects reviewed the essential approaches to classify the causes and problems based on local conditions.

\section{Previous Studies}

Herbsman and Ellis (1990) developed a statistical model that illustrated the quantitative relationships between influence factors and the productivity. The critical productivity influence factors can be divided into two groups: Technological factors and Administrative factors. Technological factors include design data, material properties, and location factors. Administrative factors include construction method and procedures, equipment factors, labour, and social factors. Lim and Price (1995) cited the seven factors identified as affecting overall construction productivity in 
Singapore: Buildability; Structure of the industry; Training; Mechanization and automations; Foreign labour; Standardizations; and Building controls. Zakeri et al (1996) analysed the constraints to site work on Iranian construction projects. The common problems identified were ranked through questionnaire survey method. Results indicate that the five highestranking problems are: Material shortage; Weather and site conditions; Equipment breakdown; Drawing deficiencies/changes orders; Lack of proper tools and equipment. Kadir et al (2005) studied the production factors critically influencing the site work for Malaysian residential projects. The results indicate that the top most important, frequent and severe factors that are adversely construction labour productivity at a projects level were material shortage at site and non-payment to suppliers causing the stoppage of material delivery. Cottrell (2006) established a regression model to relate the factors affecting site productivity to the process improvement initiatives executed both before and during construction stage. The model demonstrated the strong relationship of project performance to a variety of process improvement initiatives including design completeness, the definition of a project vision statement, testing oversight, and project manager experience and dedication.

As efforts have been rarely been made to obtain craft worker' input to examine the factors affecting the construction productivity, Dai et al (2007) measured the impact of 83 factors productivity factors, which had been identified through 18 focus group sessions with craft workers and their immediate supervisors on jobsites. The factors were categorized into eleven groups: Supervisor direction; Communication; Safety; tools and consumables; Materials; Engineering drawing management; Labour; Foreman; Superintendent;
Project management; and Construction equipment. Makulsawatudom and Emsley (2001) conducted a questionnaire survey to collect views from craftsmen working on five construction projects on the factors affecting construction productivity. Eight factors that have the most effect on construction productivity are concluded: Lack of material; Lack of tools and equipment; Incomplete drawings; Overcrowding; Poor site conditions; Tools/equipment breakdown; Incomplete supervisor; and Rework.

There are studies focused on reviewing the degree of impact of the important factors to the productivity. Moselhi, Assem and Ei-Rayes (2005) investigated the impact of change orders on construction productivity and introduced a new neural network model for quantifying the impact. The change orders factors that affect labour productivity include intensity of the orders, timing in relation to projection, work type, type of impact, project phase, on-site management. The impact of subcontracting on site productivity was evaluated through a questionnaire survey on general contractors in Taiwan (Hsieh, 1998). The survey findings demonstrate that contractual and behavioral linkages between firms are not only for the realization of an attractive gain from productivity improvement but also for an agreeable benefit-sharing mechanism between firms. Financial incentives are very effective to improve site productivity. A questionnaire survey was conducted by Fagbenle, Adeyemi and Adesanya (2004) to determine the impact of non-financial incentives on bricklayers' productivity in Nigeria. Fifteen common non-financial incentive schemes were selected for the survey. The analysis of the survey concluded that non-financial incentive schemes could motivate bricklayers and increase the productivity in bricklaying work for 6 to $26 \%$.

Many of the factors affecting the productivity at the site work level discussed in these publications such as the communication problem, tools and material shortage etc can be regarded as site coordination problems. Nineteen commonly occurred site coordination problems caused by the main contractors that adversely influenced subcontractors' site work were identified through the literature review on these publications, observed common industrial practices and advice from experienced industrial practitioners ( $\mathrm{Ng}$ and Price, 2005). They were classified into the following eight groups of problems according to their nature as shown in Table 1.

- Construction information

- Working programme

- Preparation for work place

- Interfacing work to be completed by other subcontractors

- Access to work place

- Plant support

- Material support

- Response to site problem

\section{Hong Kong projects}

Some studies have been conducted to identify the success factors for Hong Kong projects. Tam and Harris (1996) developed a model to predict the performance of the main contractors in local construction projects from the client's perspective. The resulting models produced six significant variables: Quality of the management-professional qualifications; Quality of management teamproject leader's experience; Complexity of the project; Contractor's past performance or image; Architect's or client's supervision; and Control of the quality of work and work progress. These variables were used to measure the three dimensions of a project: Inherent characteristic of the project; Contractor's internal attributes; and External influence of the project team.

Kumaraswamy and Chan (1995) established a hierarchy to illustrate the factors that can contribute to construction project duration in Hong Kong. 
Short notice to commence site work

$\mathrm{SCP} 1$

Late to provide plant support

$\mathrm{SCP} 2$

Interfacing work not yet completed

$\mathrm{SCP}_{3}$

Interfacing work not accurately completed

$\mathrm{SCP}_{4}$

Construction information not detail enough

$\mathrm{SCP}_{5}$

Construction information unclear or contradictory

SCP6

Table 1. Critical site coordination problems

Construction time can be considered to be a function of all such primary, secondary and tertiary factors in the hierarchy of determinants of construction project duration.

Chan and Kumaraswamy (1998) conducted a similar study focused on the causes of construction delays in Hong Kong. The study classified the essential factors governing construction durations into eight categories: Project-related factors; Clientrelated factors; Design team-related; Contractor-related factors; Materialrelated factors; Labour-related factors; Plant/equipment-related factors; and External factors.

Dissanayaka and Kumaraswamy (1999; 1999) evaluated the factors affecting the time and cost performance on Hong Kong building projects and grouped them into macro variables, each of which then 'covered' a large number of micro variables. All the selected micro variables may not be of the same importance in every project but may vary with the client's objectives, priorities, project conditions, constraints and complexities and the quality of the project team. The variables were also grouped into procurement and non-procurement variables.

Leung, Ng and Cheung (2004) adopted a new approach to review the success factors of projects in Hong Kong. The results of the study indicate that the satisfaction of the participants of a building project is more important to project success than meeting any particular project objectives and management mechanisms rather than particular project goal could directly affect the participant satisfaction. Cooperation/participation, task/team conflict and goal commitment are the critical factors influencing the final outcome (satisfaction) in the complicated management process.

These publications discussed the essential approaches to classify the success factors of projects in Hong Kong. These approaches were useful for establishing the method to categorize the site coordination problems and the causes to these problems. The model developed by Tam and Harris (1996) to measure the three dimensions of a project was found mostly suited for this research.

\section{Critical site coordination problems}

Among the nineteen commonly occurred site coordination problems caused by the main contractors that adversely influenced subcontractors' site work, six critical problems listed in Table 1 were shortlisted by a questionnaire survey of previous study that assessed the aggregated importance score of each site problem $\mathrm{Ng} \&$ Price (2005). In the study, aggregated importance score was designed based on the model developed by and Kadir et al (2005) and it was taken as the combined score of frequency of occurrence and the potential degree of impact to the performance of subcontractors.

Causes of site coordination problems Sixteen common causes leading to the site coordination problems were identified through literature review, observed common industrial practices and advice from experienced industrial practitioners ( $\mathrm{Ng}$ and Price, 2010). Based on the model developed by Tam and Harris (1996), they are grouped into the following three categories.

- Technical related causes

- Management system related causes

- Staffing related causes

\section{Technical related causes}

Robbins (2005) defined the term technology as to how an organisation transferred its inputs into outputs. As the role of main contractors have already transformed from a constructor to a manager of subcontractors, they should have adequate technical capacity to provide necessary assistance to subcontractors to perform efficiently and effectively.

\section{Management system related causes}

The responsibilities and duties of each member of the project team should be well defined to ensure the activities to proceed without any problems. During the project development process, a dynamic temporarily multiorganisation system is often created that is continuously confronted with disparities between two levels of objectives: the temporary objectives of the construction project; and longterm objectives of the participating organisations and operational phase of the project (Mohsini and Davidson, 1992). Main contractors need to establish dynamic management systems that facilitate the coordination of activities and control the performance of their staff members. 


\section{Staffing related causes}

There is no guarantee to the success of a project even though main contractor can establish a well organised management system and possess the necessary technical knowledge to meet the nature of the project. Main contractor have to assign adequate staff with necessary technical knowledge and experience to operate the management system.

Among them, twelve essential causes listed in Table 2 were shortlisted by a questionnaire survey of previous study that assessed the aggregated importance score of each causes ( $\mathrm{Ng}$ and Price, 2010). Aggregated importance score was designed based on the model developed by Kadir et al (2005). It was taken as the combined score of frequency of occurrence and the contribution of the causes to the site coordination problems.

Applications of Multiple Regression Analysis and Neural Networks

\section{Analysis}

The literature review undertaken shows that multiple regression analysis is a common method for the researches involving forecasting models. Regression techniques often have been used because of their relative simplicity in both concept and application. It has the ability to develop causal models where the structural relationships of the variable can be established in a predictable and explanatory way. Walker (1995) used multiple regression analysis to build up models to forecast the time performance for projects in Australia based on four variables. Chan and Kumaraswamy (1999), and Leung and Tam (1999) applied this technique to establish models to predict the overall duration and the hoisting time for a tower crane respectively for public housing projects. Skitmore and $\mathrm{Ng}$ (2003) adopted the same statistical approach using forward cross validation procedure to forecast the construction time and cost for the projects in Australia based on six variables. For the multiple regression equations generated in this study, the chance of occurrence of the critical site coordination problem is the dependent variable and the twelve essential causes are the independent variables as per Equation 1.

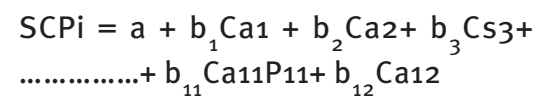

Where SCPi (critical site coordination problems) are the dependent variables

Cai (essential causes) are the independent variables

$a$ is a constant which is the $y$-intercept

$b_{i}$ is the partial regression coefficient for Cai

Equation 1: Form of multiple regression equation

Some of the variables of the regression equations can be eliminated without

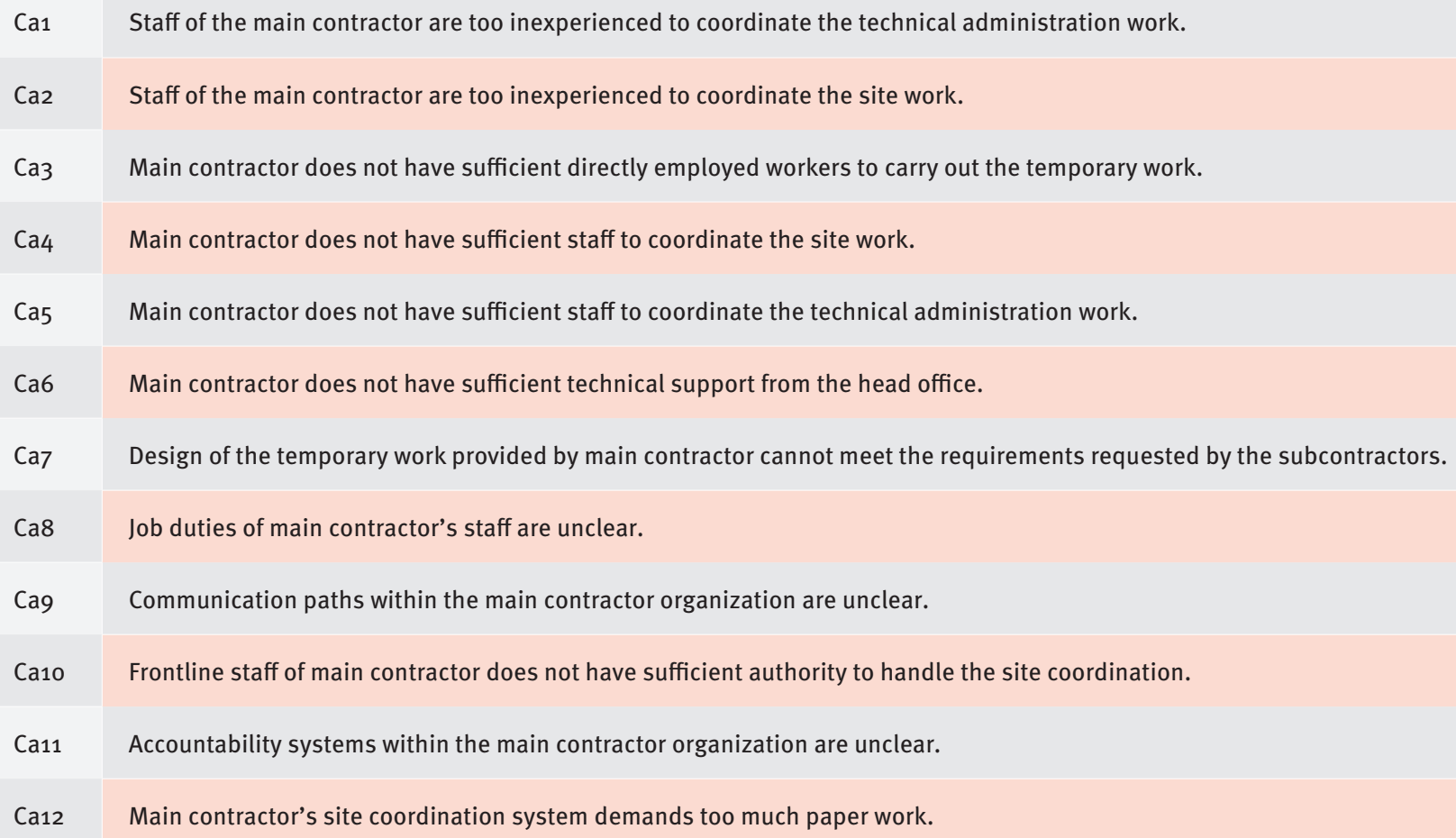


having significant impact to the accuracy of the regression equations. The backward elimination method was adopted to reduce the number of computations. The variable was eliminated if probability of F-to-remove was equal or greater than 0.100 . In each stage of elimination process, the most insignificant independent variable was removed. The process would be terminated until no variable satisfied the elimination condition such that the 'most essential' causes were kept in the last stage of regression equation.

The major conceptual limitation of all regression techniques is that one can only ascertain relationships, but never be sure about underlying causal mechanism. As for cross reference purpose, neural networks technique was adopted to validate whether multiple regression is an appropriate form to represent the relationship between the causes and the critical site coordination problems. Neural networks analysis has been commonly adopted in the recent researches because it is designed to capture functional forms automatically, allowing the uncovering of hidden nonlinear relationships between the modeling variables. The models formulated by Bhokha and Ogunlana (1999), based on eleven independent variables and a threelayered back-propagation network to forecast the construction duration at the predesign stage of buildings in Greater Bangkok, and the model formulated by Khosrowshahi (1999), based on eleven variables and a stochastic back-propagation paradigm with one hidden layer to predict the performance of the contractor at tender stage are typical applications of neural network analysis. This technique was also widely adopted in other studies such as: forecasting the cost index (Wang and Mei, 1998) and equipment productivity (OK and Sinha, 2006); selection of vertical formwork systems (Tam et al, 2005); and assessing the maintainability of building façade (Chew, Silva and Tan, 2004).
NeuroShell2 software was selected for this study. A three-layer backpropagation paradigm neural network model was used to analyse the data. Ten per cent of the data were extracted as the 'test set' for the network. As the nature of the problem is not a simple problem, complex and noisy mode was selected. This action set the learning rate and momentum factors to 0.05 And 0.5 Respectively. The number of hidden neurons was set to default number. The calibration interval was set to 50 in order to achieve maximum accuracy. The training was stopped when the new test set average errors was climbing generally or at least not close to the lowest that has been shown. This software would compile a file to compare the actual and predicted outputs, and calculate the correlation coefficient of the hidden network which could be used to measure the reliability of the network analysis.

\section{Research methodology}

Questionnaire survey method was adopted in this study. The questionnaires were distributed to industrial practitioners through private relationship and posted to subcontracting firms based on the information provided in the hong kong builders directory.

Respondents were requested to complete the questionnaire based on their current projects or the projects with highest contract sum if they were handling several projects at the same time currently. In the questionnaire, they were requested to rate: from o (never happen) to 10 (happen every site activities) with 0.5 Interval for the frequency of occurrence for each of the six critical site coordination problems; and from o (totally disagree) to 10 (totally agree) with a 0.5 Interval to represent their views on the contributions of the essential causes to the occurrence of the critical site coordination problems. The data collected would be of 'selfassessed' nature by the respondents. The impact of the 'subjectivity' to the survey is alleviated as about two hundreds set of data were collected.

\section{Data Analysis}

Type of respondent

One hundred and ninety-seven valid replies were collected for the analysis of the causes of the site coordination problems. The respondents were grouped into three headings shown in Table 3.

\section{Coding system}

The coding system shown in Table 1 and Table 2 is used to simplify the description of the repeated terms and enhance the understanding of the flow of the data analysis work in this paper.

The typical regression equations of this analysis comprised twelve independent variables. For ease of reference, the regression equation containing all the variables is called standard form regression equation (SCP-AR-1). The last stage regression equation containing the 'most essential' causes to

\begin{tabular}{|l|l|}
\hline Respondent & Number of reply \\
\hline Subcontractors & 117 \\
\hline Main contractors & 55 \\
\hline Consultants and clients & 25 \\
\hline Total & 197 \\
\hline
\end{tabular}

Table 3. Type of respondent 


\begin{tabular}{|c|c|c|c|c|}
\hline Causes & $\begin{array}{l}\text { Mean } \\
\text { score }\end{array}$ & $\begin{array}{l}\text { Standard } \\
\text { deviation }\end{array}$ & $\begin{array}{c}\text { Maximum } \\
\text { score }\end{array}$ & $\begin{array}{l}\text { Minimum } \\
\text { score }\end{array}$ \\
\hline Ca9 & 6.297 & 2.178 & 10 & 1 \\
\hline Ca8 & 6.170 & 1.918 & 10 & 2 \\
\hline Ca1 & 6.127 & 1.990 & 10 & 1.5 \\
\hline Ca1o & 5.939 & 1.767 & 10 & 1 \\
\hline Ca3 & 5.660 & 1.999 & 10 & 0 \\
\hline $\mathrm{Ca}_{4}$ & 5.652 & 2.023 & 10 & 1 \\
\hline Ca12 & 5.599 & 1.964 & 10 & 1 \\
\hline $\mathrm{Ca} 2$ & $5 \cdot 561$ & 1.988 & 10 & 1 \\
\hline $\mathrm{Ca} 5$ & $5 \cdot 510$ & 1.996 & 10 & 1 \\
\hline Ca11 & 5.338 & 2.009 & 10 & 1 \\
\hline Ca7 & 5.272 & 2.022 & 9 & 1 \\
\hline Ca6 & 5.117 & 1.938 & 10 & 0 \\
\hline
\end{tabular}

Table 4. Descriptive statistics

the critical site coordination problems generated in the backward elimination process is called the simple form regression equation (SCP-AR-final). AR represents that data included all type of respondents

\section{Descriptive statistic}

The descriptive statistics for the contribution of the causes to the site coordination problems for all types of respondents has been summarized in Table 4 in a descending order of priority of their mean scores. All the causes are regarded to have essential contribution to the occurrence of the site coordination problems as their mean scores are over 5 under the 10-point scoring system. The mean score of the most essential cause, Cag is 6.297 which

\begin{tabular}{|c|c|c|}
\hline $\begin{array}{c}\text { Site coordination } \\
\text { problem }\end{array}$ & No. of outliers & No. of cases \\
\hline SCP1 & 2 & 195 \\
\hline $\mathrm{SCP}_{2}$ & 1 & 196 \\
\hline $\mathrm{SCP} 3$ & 1 & 196 \\
\hline $\mathrm{SCP} 4$ & 0 & 197 \\
$\mathrm{SCP} 5$ & 0 & 197 \\
\hline $\mathrm{SCP} 6$ & 0 & 197 \\
\hline
\end{tabular}

Table 5. Outliner

is only 1.025 higher than lowest mean score cause, Ca6. The standard deviations of the causes are around 2 and are relatively high under the 10-point scoring system.

Outlier

Mahalanobis statistical method was adopted to detect extreme cases and they were deleted from the data for the analysis. Table 5 summarizes the number of outlier for each critical site coordination problem and the total number of cases included in the analysis.

\section{Scatterplot matrix}

The scatterplot matrix analysis provides the preliminary information of relationship between each site coordination problems and the twelve causes. The plots show that the causes are fairly linearly related to site coordination problems. There is thus no need to transform the data for the multiple regression analysis.

\section{Testing hypothesis}

The test is to assure there is a relationship between the site coordination problems (dependent variable) and the selected causes (independent variables) for the study. If there is no relationship between the independent variables and the dependent variable, the regression coefficient should be equal to zero. The hypothesis is:

Ho: $=b_{1}=b_{2}=b_{3}=b_{4}=b_{5} \ldots \ldots \ldots .$. $\mathrm{bk}=\mathrm{o}$

versa $\mathrm{Ha}$ : at least one bk is not zero The hypothesis can be tested by using the F-statistic:

\section{$\mathrm{F}=\mathrm{MSR} / \mathrm{MSE}$}

Where MSR is the mean of the sum squares for regression

MSE is the mean of sum of squares for Error

\section{Equation 2: F-statistic}

If the F-statistic is large and the observed significance level is small, 


\begin{tabular}{|c|c|c|}
\hline Code & F values & Significance level \\
\hline SCP1 & 7.903 & 0.000 \\
\hline SCP2 & 7.108 & 0.000 \\
\hline $\mathrm{SCP}_{3}$ & 7.108 & 0.000 \\
\hline $\mathrm{SCP} 4$ & 4.305 & 0.000 \\
\hline $\mathrm{SCP} 5$ & 4.819 & 0.000 \\
\hline $\mathrm{SCP} 6$ & 4.149 & 0.000 \\
\hline
\end{tabular}

Table 6. F-statistics results

the hypothesis that $b k=0$ is rejected. At least one of the regression coefficients is thus not 0 . This indicates that there is a relationship between the independent variables and the dependent variable.

The F-statistics results for this study are summarized in Table 6. The F values are not small and the observed significance values are all around 0.000 . The hypothesis that $b \mathrm{k}=0$ is thus rejected and it can be concluded that there is at least one of the coefficients is not 0 .

\section{Correlation coefficient analysis}

Pearson correlation coefficient ( $r$ ) describes how well the model fits the data. All the correlation coefficients are of possible values because the occurrence of site coordination problems is supposed to be a straight line with positive slope. The r values for each cause to each critical site coordination problem

\begin{tabular}{|l|l|l|l|l|l|l|}
\hline & $\mathrm{SCP} 1$ & $\mathrm{SCP} 2$ & $\mathrm{SCP} 3$ & $\mathrm{SCP} 4$ & $\mathrm{SCP} 5$ & $\mathrm{SCP} 6$ \\
\hline Ca1 & 0.462 & 0.352 & 0.318 & 0.291 & 0.238 & 0.299 \\
\hline $\mathrm{Ca} 2$ & 0.540 & 0.432 & 0.406 & 0.309 & 0.241 & 0.299 \\
\hline $\mathrm{Ca} 3$ & 0.394 & 0.418 & 0.401 & 0.339 & 0.338 & 0.348 \\
\hline Ca4 & 0.486 & 0.505 & 0.410 & 0.314 & 0.323 & 0.244 \\
\hline Ca5 & 0.426 & 0.486 & 0.380 & 0.283 & 0.322 & 0.252 \\
\hline Ca6 & 0.293 & 0.314 & 0.259 & 0.213 & 0.260 & 0.266 \\
\hline Ca7 & 0.363 & 0.278 & 0.291 & 0.358 & 0.335 & 0.384 \\
\hline Ca8 & 0.311 & 0.306 & 0.322 & 0.330 & 0.271 & 0.272 \\
\hline Ca9 & 0.234 & 0.209 & 0.222 & 0.350 & 0.278 & 0.276 \\
\hline Ca10 & 0.297 & 0.387 & 0.306 & 0.265 & 0.379 & 0.231 \\
\hline Ca11 & 0.317 & 0.318 & 0.282 & 0.345 & 0.332 & 0.293 \\
\hline Ca12 & 0.118 & 0.103 & 0.199 & 0.190 & 0.132 & 0.209 \\
\hline & & & & & & \\
\hline
\end{tabular}

are summarized in Table 7. The values range from 0.103 to 0.540 . As each site coordination problem is governed by twelve causes, the $r$ values indicate that most of the causes are reasonably clustered around the straight line. Regression equation generated in this study with Pearson correlation coefficient above 0.5 is regarded as liable to explain the contribution of the causes to the occurrence of the site coordination problems.

$\mathrm{R}$ Square is the square of the correlation coefficient that describes what proportion of the variability of the dependent variable is 'explained' by the regression model. Adjusted $R$ Square is an estimate of how well the model fits another data set from the same population. Since the slope and the intercept are based on the values of the first set of data, the model fits the first set of data somewhere better than it would another sample of cases. The value of Adjusted $\mathrm{R} 2$ is thus always smaller than the value of R2. Table 8 summarizes the $R$ value of the of the standard form regression equations in the descending order of priority of their $R$ values. The $R$ values of the equations range from 0.585 to 0.461 and the Adjusted R Square values of the equations range from 0.299 to 0.162 .

\section{Selecting variables}

Some of the variables of the regression equations can be eliminated without having significant impact to the accuracy of the regression equations. The backward elimination method was adopted to reduce the number of computations. Table 9 summarizes the simple form of regression equations for each critical site coordination problems in a descending order of priority of its $R$ values which ranges from 0.573 to 0.428 . The Adjusted R Square values of the equations range from 0.318 to 0.175 .

Neural network analysis

Table 10 compares the correlation coefficients of the regression equations generated by multiple regression 


\begin{tabular}{|c|c|c|c|c|}
\hline Model & Regression equation & $\mathbf{R}$ value & R Square & $\begin{array}{l}\text { Adjusted } \\
\text { R Square }\end{array}$ \\
\hline SCP1-AR-1 & $\begin{array}{c}\mathrm{SCP}_{1}=2.115+0.086 \times \mathrm{Ca}_{1}+0.223 \times \mathrm{Ca}_{2}-0.026 \times \mathrm{Ca}_{3}+0.073 \times \mathrm{Ca}_{4} \\
+0.077 \times \mathrm{Ca}_{5}-0.054 \times \mathrm{Ca} 6+0.126 \times \mathrm{Ca}_{7}-0.017 \times \mathrm{Ca}-0.028 \times \mathrm{Ca} 9+ \\
0.051 \times \mathrm{Ca} 10+0.037 \times \mathrm{Ca}_{11}-0.016 \times \mathrm{Ca}_{12}\end{array}$ & 0.585 & 0.343 & 0.299 \\
\hline $\mathrm{SCP}_{2}-\mathrm{AR}-1$ & $\begin{array}{c}\mathrm{SCP}_{2}=1.187-0.007 \times \mathrm{Ca}_{1}+0.046 \times \mathrm{Ca}_{2}+0.081 \times \mathrm{Ca}_{3}+0.122 \times \mathrm{Ca}_{4} \\
+0.133 \times \mathrm{Ca} 5+0.010 \times \mathrm{Ca} 6+0.011 \times \mathrm{Ca} 7+0.050 \times \mathrm{Ca} 8-0.050 \times \mathrm{Ca} 9+ \\
0.141 \times \mathrm{Ca} 10+0.055 \times \mathrm{Ca} 11-0.068 \times \mathrm{Ca}_{12}\end{array}$ & 0.570 & 0.324 & 0.280 \\
\hline $\mathrm{SCP}_{3}-\mathrm{AR}-1$ & $\begin{array}{c}\mathrm{SCP}_{3}=2.182-0.063 \times \mathrm{Ca}_{1}+0.147 \times \mathrm{Ca}_{2}+0.115 \times \mathrm{Ca}_{3}+0.053 \times \mathrm{Ca}_{4} \\
+0.090 \times \mathrm{Ca}_{5}-0.055 \times \mathrm{Ca}_{6}+0.045 \times \mathrm{Ca} 7+0.093 \times \mathrm{Ca} 8-0.019 \times \mathrm{Ca} 9+ \\
0.069 \times \mathrm{Ca}_{10}-0.033 \times \mathrm{Ca} 11+0.068 \times \mathrm{Ca}_{12}\end{array}$ & 0.498 & 0.248 & 0.199 \\
\hline $\mathrm{SCP}_{5}-\mathrm{AR}-1$ & $\begin{array}{c}\mathrm{SCP}_{5}=3.536+0.025 \times \mathrm{Ca}_{1}-0.093 \times \mathrm{Ca} 2+0.112 \times \mathrm{Ca}_{3}-0.013 \times \mathrm{Ca}_{4} \\
+0090 \times \mathrm{Ca} 5+0.015 \times \mathrm{Ca} 6+0.140 \times \mathrm{Ca} 7-0.049 \times \mathrm{Ca} 8+0.027 \times \mathrm{Ca}+ \\
0.216 \times \mathrm{Ca} 10+0.074 \times \mathrm{Ca} 11-0.068 \times \mathrm{Ca}_{12}\end{array}$ & 0.489 & 0.239 & 0.190 \\
\hline SCP4-AR-1 & $\begin{array}{c}\mathrm{SCP}_{4}=3.022+0.005 \times \mathrm{Ca}_{1}+0.041 \times \mathrm{Ca} 2+0.078 \times \mathrm{Ca}_{3}-0.002 \times \mathrm{Ca}_{4} \\
+0.095 \times \mathrm{Ca}_{5}-0.093 \times \mathrm{Ca} 6+0.138 \times \mathrm{Ca} 7+0.005 \times \mathrm{Ca} 8+0.110 \times \mathrm{Ca} 9+ \\
0.023 \times \mathrm{Ca} 10+0.037 \times \mathrm{Ca} 11+0.031 \times \mathrm{Ca} 12\end{array}$ & 0.468 & 0.219 & 0.168 \\
\hline SCP6-AR-1 & $\begin{array}{c}\mathrm{SCP} 6=2.911+0.042 \times \mathrm{Ca}_{1}+0.060 \mathrm{Ca} 2+0.122 \times \mathrm{Ca}_{3}-0.126 \times \mathrm{Ca}_{4} \\
+0074 \times \mathrm{Ca} 5-0.015 \times \mathrm{Ca} 6+0.196 \times \mathrm{Ca} 7-0.067 \times \mathrm{Ca} 8+0.031 \times \mathrm{Ca} 9+ \\
0.050 \times \mathrm{Ca} 10+0.046 \times \mathrm{Ca}_{11}+0.054 \times \mathrm{Ca} 12\end{array}$ & 0.461 & 0.213 & 0.162 \\
\hline
\end{tabular}

Table 8. Standard form regression equation

\begin{tabular}{|c|c|c|c|c|}
\hline Model & Regression equations & $\mathbf{R}$ value & R Square & $\begin{array}{l}\text { Adjusted } \\
\text { R Square }\end{array}$ \\
\hline SCP1-AR-final & $\begin{array}{l}\mathrm{SCP}_{1}=2.284+0.275 \times \mathrm{Ca}_{2}+0.129 \times \mathrm{Ca}_{4}+ \\
0.103 \times \mathrm{Ca}_{7}\end{array}$ & 0.573 & 0.328 & 0.318 \\
\hline SCP2-AR -final & $\begin{array}{l}\mathrm{SCP}_{2}=1.844+0.199 \times \mathrm{Ca}_{4}+0.169 \times \mathrm{Ca}_{5}+ \\
0.140 \times \mathrm{Ca} 10\end{array}$ & 0.552 & 0.304 & 0.293 \\
\hline $\mathrm{SCP}_{3}$-AR-final & $\begin{array}{l}\mathrm{SCP} 2=2.562+0.153 \times \mathrm{Ca}_{2}+0.162 \times \mathrm{Ca}_{3}+ \\
0.119 \times \mathrm{Ca} 8\end{array}$ & 0.466 & 0.217 & 0.205 \\
\hline SCP4-AR-final & $\begin{array}{l}\mathrm{SCP}_{4}=3.271+0.129 \times \mathrm{Ca}_{5}+0.151 \times \mathrm{Ca}_{7}+ \\
0.149 \times \mathrm{Ca}_{9}\end{array}$ & 0.443 & 0.197 & 0.184 \\
\hline SCP5-AR-final & $\begin{array}{l}\mathrm{SCP}_{5}=2.394+0.121 \times \mathrm{Ca}_{3}+0.137 \times \mathrm{Ca}_{7}+ \\
0.235 \times \mathrm{Ca} 10\end{array}$ & 0.469 & 0.220 & 0.208 \\
\hline SCP6-AR-final & $\mathrm{SCP} 6=3.454+0.161 \times \mathrm{Ca}_{3}+0.208 \times \mathrm{Ca} 7$ & 0.428 & 0.183 & 0.175 \\
\hline
\end{tabular}

Table 9. Simple form regression equation

analysis and neural network analysis. The table shows that correlation coefficients computed by these two methods are quite consistent except the SCP4-AR-final and $\mathrm{SCP}_{3}-\mathrm{AR}-1$ of which the different are 0.314 and 0.188 respectively.

Importance analysis

Among the twelve causes, some of them are more important. They were identified by backward elimination method and are regarded as the 'most essential' causes. The 'most essential' causes are the independent variable remained in 


\begin{tabular}{|c|c|c|c|c|}
\hline Model & $\mathbf{A}$ & B & C & D \\
\hline SCP1-AR -1 & All & 0.585 & 0.630 & 0.045 \\
\hline SCP1-AR - final & $\mathrm{Ca}, \mathrm{Ca}_{4}, \mathrm{Ca} 7$ & 0.573 & 0.587 & 0.014 \\
\hline $\mathrm{SCP}_{2}-\mathrm{AR}-1$ & All & 0.570 & 0.490 & 0.080 \\
\hline $\mathrm{SCP}_{2}-\mathrm{AR}$ - final & $\mathrm{Ca}_{4}, \mathrm{Ca}_{5}, \mathrm{Ca} 10$ & 0.552 & 0.542 & 0.010 \\
\hline $\mathrm{SCP}_{3}-\mathrm{AR}-1$ & All & 0.498 & 0.686 & 0.188 \\
\hline $\mathrm{SCP}_{3}$-AR-final & $\mathrm{Ca} 2, \mathrm{Ca}_{3}, \mathrm{Ca} 8$ & 0.466 & 0.490 & 0.024 \\
\hline $\mathrm{SCP}_{4}-\mathrm{AR}-1$ & All & 0.468 & 0.567 & 0.099 \\
\hline SCP4-AR-final & Ca5, Ca7, Ca9 & 0.443 & 0.757 & 0.314 \\
\hline $\mathrm{SCP}_{5}-\mathrm{AR}-1$ & All & 0.489 & 0.440 & 0.049 \\
\hline $\mathrm{SCP}_{5}-\mathrm{AR}$ - final & Ca3, Ca7, Ca1o & 0.469 & 0.468 & 0.001 \\
\hline SCP6-AR -1 & All & 0.461 & 0.449 & 0.012 \\
\hline SCP6-AR - final & $\mathrm{Ca}_{3}, \mathrm{Ca} 7$ & 0.428 & 0.427 & 0.001 \\
\hline
\end{tabular}

A: Independent variables included in the multiple regression equation

B: Correlation coefficient computed by multiple regression analysis

C: Correlation coefficient computed by neural network analysis

D: Difference of B and $C$.

\section{Table 10. Neural network analysis}

the simple form of regression equation. Table 11 and Figure 2 relate the 'most essential' causes to the critical site coordination problems. The analysis provides guideline to main contractors to focus their efforts in handling the 'most essential' causes in order to eliminate the site coordination problems.

\section{Conclusion}

In Hong Kong building projects, most of the site works are actually carried out by subcontractors. The role of main contractors have gradually transformed from a constructor to a manager of subcontractors of projects. The performance of subcontractors directly affects the outcome of a project. With rapid development of high-rise building projects, there are increasing complaints from subcontractors that they are unable to efficiently and effectively perform their site works due to main contractors' poor site coordination. Six critical site coordination problems to the performance of subcontractors and twelve essential causes to the problems were identified. A questionnaire survey was conducted to establish a model in the form of multiple regression equation to explain the contributions of the causes to each of the critical site coordination problems. The multiple regression equations were summarized in Table 8. Taking into account that the equations consist of twelve causes, they are good to explain the relationship between the causes and the problems as their $\mathrm{R}$ values are around 0.5 .

Based on the Importance analysis, 'design of the temporary work provided by main contractor cannot meet the requirements requested by the subcontractors (Ca7)' is the most important causes as it is the 'most essential' causes of four out of the six critical site coordination problems. Thus main contractors should pay special attention in designing the temporary work to subcontractors so as to optimize their performance. 'Staff of the main contractor are too inexperienced to coordinate the technical administration work (Ca1)', 'main contractor does not have sufficient technical support from the head office (Ca6)', 'accountability systems within the main contractor organization are unclear (Ca11)' and 'main contractor's site coordination system demands too much paper work (Ca12)' are less essential causes as they are not included in any of the simple form regression equation. 
Staffs of the main contractor are too inexperienced to coordinate the technical administration work. (Ca1)

Staffs of the main contractor are too inexperienced to coordinate the site work. (Ca2)

Main contractor does not have sufficient directly employed workers to carry out the temporary work. (Саз)

Main contractor does not have sufficient staff to coordinate the site work. (Ca4)

Main contractor does not have sufficient staff to coordinate the technical administration work. (Ca5)

Main contractor does not have sufficient technical support from the head office. (Ca6)

Design of the temporary work provided by main contractor cannot meet the requirements requested by the subcontractors. (Ca7)

Job duties of main contractor's staff are unclear. (Ca8)

Communication paths within the main contractor organization are unclear. (Cag)

Frontline staff of main contractor does not have sufficient authority to handle the site coordination. (Ca10)

Accountability systems within the main contractor organization are unclear. (Ca11)

Main contractor's site coordination system demands too much paper work. (Ca12)
Short notice to commence site work ( $\left.\mathrm{SCP}_{1}\right)$; Interfacing work not yet completed $\left(\mathrm{SCP}_{3}\right)$

Interfacing work not yet completed ( $\left.\mathrm{SCP}_{3}\right)$;

Construction information not detail enough ( $\left.\mathrm{SCP}_{5}\right)$;

Construction information unclear or contradictory (SCP6)

Short notice to commence site work ( $\left.\mathrm{SCP}_{1}\right)$;

Late to provide plant support $\left(\mathrm{SCP}_{2}\right)$

Late to provide plant support ( $\left.\mathrm{SCP}_{2}\right)$;

Interfacing work not accurately completed $\left(\mathrm{SCP}_{4}\right)$

Short notice to commence site work ( $\left.\mathrm{SCP}_{1}\right)$;

Interfacing work not accurately completed ( $\left.\mathrm{SCP}_{4}\right)$;

Construction information not detail enough ( $\left.\mathrm{SCP}_{5}\right)$;

Construction information unclear or contradictory (SCP6)

Interfacing work not yet completed ( $\left.\mathrm{SCP}_{3}\right)$

Interfacing work not accurately completed (SCP4)

Late to provide plant support ( $\left.\mathrm{SCP}_{2}\right)$;

Construction information not detail enough $\left(\mathrm{SCP}_{5}\right)$

\section{Table 11. Importance analysis}

\section{References}

Bhokha S. and Ogunlana S. O. (1999),

"Application of artificial neural network to

forecast construction duration of buildings

at the predesign stage", Engineering,

Construction and Architectural Management,

1996 6/2, 133-144.

Census and Statistics Department (2010),

“Statistical Report: 2010", Hong Kong SAR

Government.

Chan, D. W. M. and Kumaraswamy, M. M. (1995),

"A study of the related factors affecting

construction durations in Hong Kong",

Construction Management and Economics,

(13), 319-333.

Chan, D. W. M. and Kumaraswamy, M. M. (1999),

"Modelling and predicting construction

durations in Hong Kong public housing”,
Construction Management and Economics,

(1999), 17, 351-362.

Chew M. Y. L., Silva N D. and Tan S. S. (2004),

"A neural network approach to assessing building façade maintainability in the tropics", Construction Management and Economics, (22), 581-594.

Cottrell, D. S. (2006), “Contractor Process Improvement for Enhancing Construction Productivity", Journal of Construction Engineering and Management, Feb. 2006 p189-196

Dai, J., Goodrum, P. M., and Maloney, W. F. (2007), “Analysis of craft workers' and foreman's perceptions of the factor affecting construction labour productivity", Construction Management and Economics, (25), 1139-1152
Dissanayaka, S. M. and Kumaraswamy, M.

M. (1999), "Evaluation of factors affecting time and cost performance in Hong Kong building projects”, Engineering, Construction and Architectural Management, (6/3), 287-298.

Dissanayaka, S. M. and Kumaraswamy, M. M. (1999), "Comparing contributors to time and cost performance in building projects", Building and Environment, (34) 31-42.

Fagnenle, O. I., Adeyemi, A. Y. and Adesanya, D. A. (2004), "The impact of non-financial incentives on bricklayers' productivity in Nigeria", Construction Management and Economics, (22), 899-911.

Herbsman Z. and Ellis, E. (1990), “Research of factors influencing construction productivity", Construction Management and Economics, (8), 49-61. 


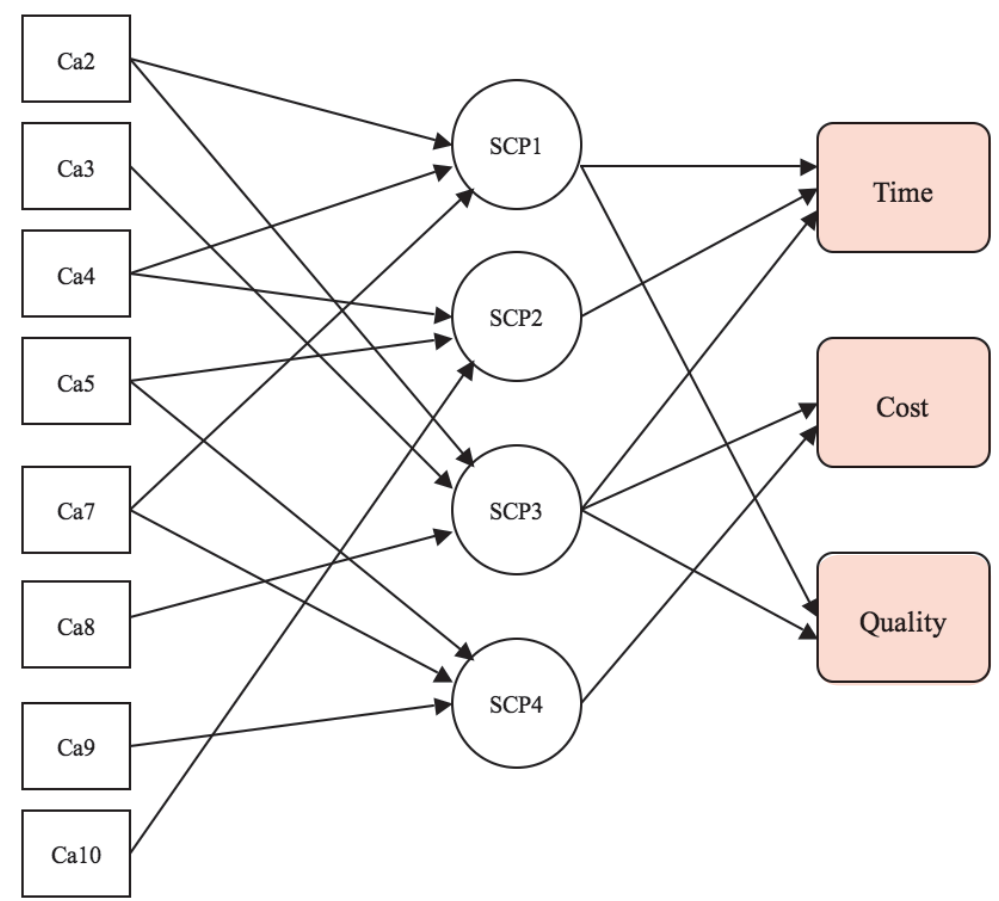

Figure 2. Relationship between 'most essential' causes and site coordination problems
Hsieh, T (1998), “Impacts of Subcontracting on Site Productivity: Lessons Learned in Taiwan”, Journal of Construction Engineering and Management, 124(2), 91-100.

Kadir, M. R. Abdul, Lee, W. P., Jaafar, M. S., Sapuan, S. M., \& Ali, A. A. A. (2005), "Factors affecting construction labour productivity for Malaysian residential projects", Structural Survey, Vol. 23 No.1 2005, 42-54.

Khosrowshahi F. (1999), “Neural network model for contractors' prequalification for local authority projects”, Engineering, Construction and Architectural Management, (6/3), 315-328.

Kinnear, P. R. and Gray, D. C. (2008), SPSS15 Made Simple, Taylor \& Francis Group.

Leung, M. Y., Ng T. S., and Cheung S. O. (2004), "Measuring construction project participant satisfaction”, Construction Management and Economic, (22), 319-331.

Leung A. W. T. and Tam C. M. (1999), “Prediction of hoisting time for tower cranes for public housing construction in Hong Kong”, Construction Management and Economics (17), 305-314.

Leung A. W. T. and Tam C. M. (1999), "Prediction of hoisting time for tower cranes for public housing construction in Hong Kong”, Construction Management and Economics (17), 305-314.

Lim, E. C. and Price, A. D. F (1995), “Construction productivity measurements for residential building in Singapore", Proceedings of First International Conference on Construction Management, Singapore, January 605-12.

Ng, K. W. A. and Price, A. D. F. (2005), “Assessing the impact of main contractor's site coordination on subcontractors' performance in Hong Kong", 21th Annual Conference 2005, Association of Researchers in Construction Management, U.K.

Ng, K. W. A. and Price, A. D. F. (2010), “Causes Leading to Poor Site Coordination in Building Projects”, Organisation, Technology \& Management in Construction: An International Journal, Vol. 2, Issue No.2.

Mohsini, R. A. and Davidson, C. H. (1992), "Determinants of performance in the traditional building process", Construction Management and Economics, (10), 343-359.

Moselhi, O., Assem, I., Ei-Rayes, K. (2005), "Change Orders Impact on Labor Productivity", Journal of Construction Engineering and Management, March 2005, p354-359.

Ok, S. C. and Sinha, S. K. (2006), “Construction equipment productivity estimation using artificial neural network model”, Construction Management and Economics (24), 1029-1044.

Robbins, S. P. (2005), Organizational behaviour, Prentice-Hall International Editions.
Skitmore, R. M. and Ng, S. T. (2003), “Forecast models for actual construction time and cost”, Building and Environment 38(8) 1075-83.

Sozen, Z. and Kucuk, M. A. (1999), "Secondary subcontracting in the Turkish construction industry", Construction Management and Economics, (17), 215-220.

Tam, C. M., Deng, Z. M., Zeng, S. X., and Ho, C. S. (2000), "Quest for continuous quality improvement for public housing construction in Hong Kong", Construction

Tam, C. M. and Tong, T. K. L., Lau T. C. T. and Chan K. K. (2005), "Selection of vertical formwork system by probabilistic neural networks models", Construction Management Economics, (23), 245-254.

Walker, D. (1995), “An investigation into construction time performance", Construction Management and Economics (13), 263-274.

Wang C. H. and Mei, Y. H. (1998), “Model for forecasting construction cost indices in Taiwan”, Construction Management and Economics, (16), 147-157.

Zakeri, M., Olomolaiye, P. O, Holt, G. D. and Harris, F. C. (1996), "A survey of constraints on Iranian construction operatives' productivity", Construction Management and Economics, (14), 417-426. 